\section{Autonomous Mower Saves Energy and Improves Quality of Tall Fescue Lawn}

\author{
Nicola Grossi ${ }^{1,3}$, Marco Fontanelli ${ }^{1}$, Elisa Garramone ${ }^{1}$, \\ Andrea Peruzzi ${ }^{1}$, Michele Raffaelli ${ }^{1}$, Michel Pirchio ${ }^{1}$, \\ Luisa Martelloni ${ }^{1}$, Christian Frasconi ${ }^{1}$, Lisa Caturegli ${ }^{1}$, \\ Monica Gaetani ${ }^{1}$, Simone Magni ${ }^{1}$, J. Scott McElroy ${ }^{2}$, \\ and Marco Volterrani ${ }^{1}$
}

AdDITIONAL INDEX wORDs. turfgrass, Festuca arundinacea, leaf width, turf density

SUMMARY. Battery-powered autonomous mowers are designed to reduce the need of labor for lawn mowing compared with traditional endothermic engine mowers and at the same time to abate local emissions and noise. The aim of this research was to compare autonomous mower with traditional rotary mower on a tall fescue (Festuca arundinacea) lawn under different nitrogen $(\mathrm{N})$ rates. A two-way factor experimental design with three replications was adopted. In the study, four $\mathrm{N}$ rates $(0,50$, 100 , and $150 \mathrm{~kg} \cdot \mathrm{ha}^{-1}$ ) and two mowing systems (autonomous mower vs. gasolinepowered walk-behind rotary mower equipped for mulching) were used. As expected, $\mathbf{N}$ fertilization increased turf quality. At the end of the trial, the autonomous mower increased turf density $\left(3.2\right.$ shoots $\left./ \mathrm{cm}^{2}\right)$ compared with the rotary mower $\left(2.1\right.$ shoots $\left./ \mathrm{cm}^{2}\right)$ and decreased average leaf width $(2.1 \mathrm{~mm})$ compared with the rotary mower $(2.7 \mathrm{~mm})$. Increased density and decreased leaf width with autonomous mowing yielded higher quality turf $(7.3)$ compared with the rotary mower $(6.4)$ and a lower weed incidence $(6 \%$ and $9 \%$ cover for autonomous mower and rotary mower, respectively). Disease incidence and mowing quality were unaffected by the mowing system. The autonomous mower working time was set to 10 hours per day $(\approx 7.8$ hours for mowing and 2.2 hours for recharging) for a surface of $1296 \mathrm{~m}^{2}$. The traditional rotary mower working time for the same surface was $\mathbf{1 . 0 2}$ hours per week. The estimated primary energy consumption for autonomous mower was about $4.80 \mathrm{kWh} /$ week compared with $12.60 \mathrm{kWh} /$ week for gasoline-powered rotary mowing. Based on turf quality aspects and energy consumption, the use of autonomous mowers could be a promising alternative to traditional mowers.

$\mathrm{M}$ owing is an essential cultural practice in turfgrass management removing no more than one-third of the total leaf material at any one mowing. The " $1 / 3$ rule" is used to avoid scalping and decrease physiological stress from excessive removal of leaf material (Beard, 1973). Physiological response to mowing is

This research was supported by University of Pisa, project, "Advanced technologies for an environmentally eco-friendly management of turfgrass" ("Progetti di Ricerca di Ateneo 2016").

We sincerely thank FERCAD S.p.a. Company (Altavilla Vicentina, Vicenza, Italy) for providing the autonomous mower and technical assistance, Rossi Macchine Agricole Company (Ponte a Egola, San Miniato, Pisa, Italy) for providing technical assistance, Bindi Pratopronto Nord Company (San Piero a Grado, Pisa, Italy) for hosting the trials.

${ }^{1}$ Department of Agriculture, Food and Environment (DAFE), University of Pisa, Pisa, Italy 56124

${ }^{2}$ Crop, Soil and Environmental Sciences Faculty, Auburn University, Auburn, AL 36849

${ }^{3}$ Corresponding author. E-mail: nicola.grossi@unipi.it. doi: 10.21273/HORTTECH03483-16 both positive and negative. Mowing removes photosynthetic tissues reducing the production of carbohydrates, but the plant responds and compensates with an increase in shoot density (Sheffer et al., 1978; Shepard et al., 1989; Turgeon, 1980). Leaves are consequently produced close to the ground, and in some species, the production of stolons and rhizomes can increase.
Mowing is based on height and frequency. A tall fescue lawn is generally mown once per week at $10-\mathrm{cm}$ height while sports turfgrasses such as golf courses fairways are mown more often (two to three times per week) at heights as low as 1.5 to $2.0 \mathrm{~cm}$ (Volterrani and Magni, 2004). In general, ornamental lawns in residential and nonresidential landscapes are mown with rotary-type mowers. Depending on the kind of power supply, ornamental lawn mowers, or simply "lawn mowers," can be divided in two broad categories: electric mowers and combustion engine mowers. Electric mowers must be connected to an electricity supply (an electric cord or a battery) while combustion engine mowers must be supplied with fuels (usually gasoline). In Italy, the most common mowers are electric mowers with the cord, for very small gardens, and combustion engine mowers. Battery mowers are more innovative but not widespread, probably for higher cost and for the limited surface generally mowed (up to 500 to $1000 \mathrm{~m}^{2}$ ).

Autonomous mowers are batterypowered machines (no need of electric cord), which perform mowing without requiring an operator. They can be programmed by the user to perform optimal turf maintenance and usually operate every day. Since autonomous mowers typically are programmed to cut every day, the clipping debris is smaller (few millimeters); therefore, it is unnoticeable and easily integrates in the turf to recycle N (Starr and DeRoo, 1981) and other nutrients. Autonomous mowers can provide many perceived advantages such as saving human labor; avoiding exposure to dust, allergens, and potential injury from mowing parts; and reducing pollutants (Hicks and Hall, 2000; Ragonese

\begin{tabular}{llll}
\hline $\begin{array}{l}\text { Units } \\
\begin{array}{l}\text { To convert U.S. to SI, } \\
\text { multiply by }\end{array}\end{array}$ & U.S. unit & SI unit & $\begin{array}{l}\text { To convert SI to U.S., } \\
\text { multiply by }\end{array}$ \\
\hline 0.3048 & $\mathrm{ft}$ & $\mathrm{m}$ & 3.2808 \\
0.0929 & $\mathrm{ft}^{2}$ & $\mathrm{~m}^{2}$ & 10.7639 \\
3.7854 & $\mathrm{gal}$ & $\mathrm{L}$ & 0.2642 \\
2.54 & inch $(\mathrm{es})$ & $\mathrm{cm}$ & 0.3937 \\
25.4 & inch(es & $\mathrm{mm}$ & 0.0394 \\
6.4516 & inch & $\mathrm{cm}{ }^{2}$ & 0.1550 \\
1.1209 & $\mathrm{lb} / \mathrm{acre}$ & $\mathrm{kg} \cdot \mathrm{ha}^{-1}$ & 0.8922 \\
1 & $\mathrm{mmho} / \mathrm{cm}$ & $\mathrm{dS} \cdot \mathrm{m}^{-1}$ & 1 \\
1.6093 & $\mathrm{mph}$ & $\mathrm{km} \cdot \mathrm{h}^{-1}$ & 0.6214 \\
62.5000 & $\mathrm{oz} / \mathrm{lb}$ & $\mathrm{g} \cdot \mathrm{kg}^{-1}$ & 0.0160 \\
37.0798 & $\mathrm{oz} / \mathrm{yard}$ & $\mathrm{g} \cdot \mathrm{m}^{-3}$ & 0.0270
\end{tabular}


and Marx, 2015). The first autonomous mower was launched to the market during 1995 by a Swedish company, Husquarna (Stockholm, Sweden) (MacRae, 2013).

The first autonomous mower was powered by solar energy, but currently all autonomous mowers are powered by batteries. Autonomous lawn mowers are sold mainly in Europe but this market has potential for other geographic areas. Autonomous mowers are mainly employed for home lawns and industrial green areas but also have potential for sports turfs (e.g., football pitches, golf courses). The maximum working area capacity varies from 400 to $5000 \mathrm{~m}^{2}$ for autonomous mowers designed for private or industrial green areas (Honda, 2016; Husqvarna, 2015; Robomow, 2016). Special autonomous mowers may have a capacity ranging from 5000 to $30,000 \mathrm{~m}^{2}$ (Etesia, 2016; Zucchetti, 2016).

The cutting deck of an autonomous mower usually consists of single or multiple cutting discs with "razorshaped" pivoting blades (Honda, 2016; Husqvarna, 2015) or of single or multiple solid blades with three or four cutting edges (Robomow, 2016; Zucchetti, 2016). The autonomous mowers operate within a boundary wire (usually shallow buried in the soil), which creates an electromagnetic fence (Hicks and Hall, 2000). Autonomous mowers generally move randomly following linear trajectories. In other words, autonomous mowers follow straight lines until they find the boundary wire and then change direction. This kind of pattern can be very effective for lawn areas with many obstacles but leads to mowing overlaps (Ragonese and Marx, 2015). The most recent autonomous mowers designed for large areas have options of a Global Positioning System (GPS) for a "randomassisted" pattern (Husqvarna, 2015) or a differential GPS for systematic trajectories (Zucchetti, 2016). All autonomous mowers automatically return to the charging station when their batteries reach a minimum charge level (Hicks and Hall, 2000). Some autonomous mowers may be equipped with one or two extra wires, or guide wires, which help the autonomous mower to pass through narrow passages in complex areas and to reduce the time required to reach the charging station.
To date, research on autonomous mowers is limited and has primarily focused on mowing efficiency and algorithm development, not impact on turfgrass characteristics. Chang et al. (2015) developed an autonomous electric mower and tested it on an outdoor lawn to evaluate the mowing overlap and the coverage rate. Lu et al. (2014) proposed an algorithm for recognizing uncut lawn to improve the efficiency of autonomous mowers, reaching a recognition ratio between $80 \%$ and $90 \%$. Tang and Schiehlen (2014) investigated the motion of a Husqvarna Automower ${ }^{\circledR}$ autonomous mower, derived the equation of the motion and discussed the motion strategy. The autonomous mower mows the grass forward, along straight directions. When detects the boundary or an obstacle brakes, goes backward and rotates with a random degree and starts mowing forward again (Tang and Schiehlen, 2014).

Little is known about turfgrass quality aspects and relative energy consumption of autonomous mowers compared with traditional mowers following the " $1 / 3$ rule." The aim of this research was to compare an autonomous mower with traditional rotary mower on a tall fescue turf fertilized with different $\mathrm{N}$ rates. The trial was carried out in order to simulate different $\mathrm{N}$ availability that we can find in lawns and to determine turf quality, operative performances, and energy consumption of the two mowing systems.

\section{Materials and methods}

The experimental trial was carried out in San Piero a Grado, Pisa, Italy (lat. $43^{\circ} 39^{\prime} \mathrm{N}$, long. $10^{\circ} 21^{\prime} \mathrm{E}$, elevation $5 \mathrm{~m}$ ) from Sept. 2014 to July 2015 on a stand of "Grande" tall fescue. The grass was seeded on 19 Sept. 2014 at seeding rate of $43 \mathrm{~g} \cdot \mathrm{m}^{-2}$ on a soil characterized by the following physical-chemical properties: $91 \%$ sand, $5 \%$ silt, $4 \%$ clay, $\mathrm{pH} 6.5$, $1.3 \mathrm{~g} \cdot \mathrm{kg}^{-1}$ of organic matter; electrical conductivity $0.46 \mathrm{dS} \cdot \mathrm{m}^{-1}$.

Before the seeding, fertilizer was applied with $50 \mathrm{~kg} \cdot \mathrm{ha}^{-1} \mathrm{~N}$ from urea, $22 \mathrm{~kg} \cdot \mathrm{ha}^{-1}$ phosphorous from superphosphate, and $83 \mathrm{~kg} \cdot \mathrm{ha}^{-1}$ potassium from potassium sulfate.

From November to December, broadcast fertilization was carried out for a total of $60 \mathrm{~kg} \cdot \mathrm{ha}^{-1} \mathrm{~N}$ from urea. Turfgrass was mowed at $4.5 \mathrm{~cm}$ until Apr. 2015. Irrigation was applied when necessary to avoid wilting.
On 21 Apr. 2015, a two-way factors experimental design with three replications was initiated. Factor one consisted in four levels of $\mathrm{N}$ fertilization: $0,50,100$, and $150 \mathrm{~kg} \cdot \mathrm{ha}^{-1} \mathrm{~N}$ (ammonium sulfate $21 \mathrm{~N}-0 \mathrm{P}-0 \mathrm{~K}$ ). Factor two consisted of mowing with autonomous mower (Automower ${ }^{\circledR}$ $330 \mathrm{X}$ ) set up for $10 \mathrm{~h} \cdot \mathrm{d}^{-1}$ working time and $7 \mathrm{~d}$ per week (Fig. 1) and a gasoline walk-behind rotary mower (JS63; John Deere, Moline, IL) once per week (Fig. 2 ). Mowing height of all mowers was set at $3.5 \mathrm{~cm}$. The blades of the rotary mower were sharpened every 3 weeks. The blades of the autonomous mower were replaced every 3 weeks.

The Automower ${ }^{\circledR} 330 \mathrm{X}$ is equipped with a $24-\mathrm{cm}$-wide cutting disc with three pivoting interchangeable blades. Automower ${ }^{\circledR} 330 \mathrm{X}$ has two front pivoting wheels and two rear course treaded driving wheels, three electric brushless motors, one for the cutting disc and one for each driving wheel (Fig. 1). Maximum working capacity is $3200 \mathrm{~m}^{2}$ for a $24 \mathrm{~h} \cdot \mathrm{d}^{-1}$ working time.

In this trial, the size of the whole experimental area was $2592 \mathrm{~m}^{2}$ subdivided in 24 experimental plots of $108 \mathrm{~m}^{2}(18 \times 6 \mathrm{~m})$.

For a 12 -week period from 21 Apr. to 14 July, the following parameters were visually assessed: 1) turf quality $[1=$ poor, $9=$ excellent, 6 is considered acceptable (Morris and Shearman, 2014)], 2) mowing quality as estimate of cleanliness mowing $(1=$ poorest mowing quality, $9=$ cleanest cut, 6 is considered acceptable), $3)$ disease $[1=$ completely injury, $9=$ no injury (Morris and Shearman, 2014)], and 4) weed groundcover (the percentage of ground covered by weeds).

At 12 weeks after treatment (WAT), a single $50-\mathrm{cm}^{2}$ core sample per plot was collected and the following parameters were assessed: 1) leaf width (20 fully expanded leaves per plot were measured in millimeters with precision vernier calipers) and 2) shoot density (direct counting of living shoots with data reported as shoots per square centimeter).

Statistical analysis of biometric data was carried out with COSTAT software (version 6.400; CoHort Software, Monterey, CA). All data were analyzed by two-way analysis of variance, and an all-pairwise Fisher's least significant difference test at the probability level of 0.05 . 
A

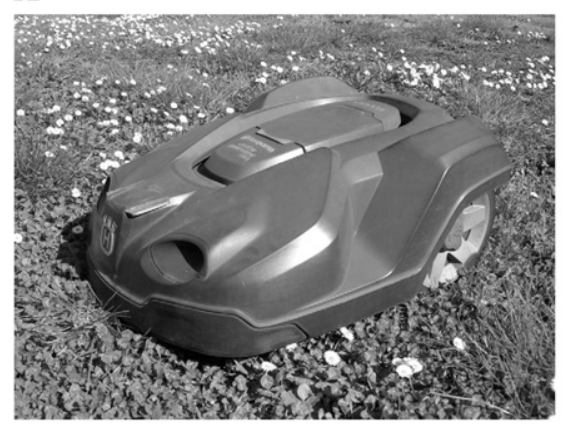

B

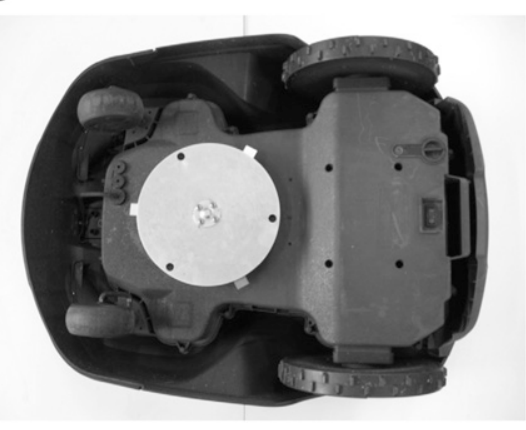

Fig. 1. (A) Autonomous mower (Automower ${ }^{\circledR}$ 330X; Husqvarna, Stockholm, Sweden) and (B) cutting disc.

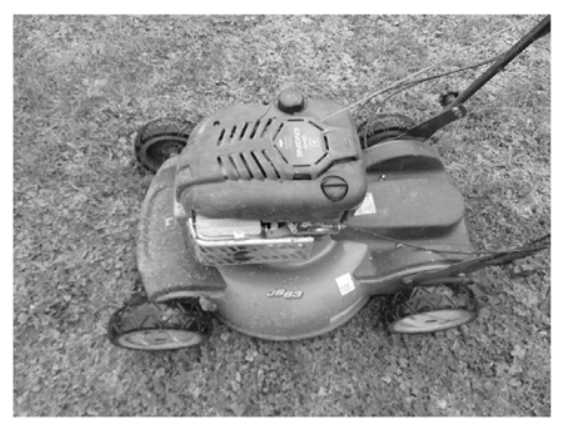

Fig. 2. Walk-behind rotary mower (JS63; John Deere, Moline, IL).

The operative characteristics of the two different mowing systems were assessed during June and July. Working speed, working time, turning time, working capacity, power requirement, electrical energy requirement, and gasoline consumption were assessed. Electrical energy requirement was assessed using a power consumption meter (EL-EPM02HQ; Nedis,'s-Hertogenbosch, The Netherlands). Gasoline consumption was measured by refueling the fuel tank after mowing. The tank was fully filled before and after mowing. The second refuelling gives the fuel consumption. Primary energy consumption (energy contained in raw fuels) of the two mowing systems was estimated using the following conversion factors: 9.2 $\mathrm{kWh} /$ L of gasoline (Gupta, 2014) and efficiency of 0.46 for the Italian $\mathrm{Na}$ tional Electric System (European Union, 2014). A cost comparison between the two machines was realized, referring to the study area. The estimation included fixed costs (purchase cost as depreciation) and variable costs (fuel and lubricant consumption for the ordinary rotary mower, electric energy consumption for the autonomous

mower, labor for the ordinary rotary mower, maintenance for both the machines). The estimated machine life was 10 years for both the machines. It was estimated that at the end of their life, both machines would have no commercial value. The purchase cost was 3360 euros for the autonomous mower and 894 euros for the rotary mower. The gasoline cost was 1.44 euro/h. The labor cost was 25 euros/ h. The total working period per season was considered $210 \mathrm{~d}$.

\section{Results}

There was no significant interaction between $\mathrm{N}$ fertilization and mowing system for any of the studied parameters. For most of the parameters, main effects of $\mathrm{N}$ fertilization and mowing system were statistically significant $(P<0.05)$. Thus, main effects of $\mathrm{N}$ fertilization and mowing system will be presented in this work. As expected, 7 WAT, $\mathrm{N}$ fertilization improved turf quality values $(>6.2)$ compared with control $[5.2$ (no N fertilization)] (Table 1). Mowing quality was also improved by $\mathrm{N}$ fertilization, although mowing quality of control was acceptable. Weed cover percentage and disease incidence were unaffected by $\mathrm{N}$ fertilization.

At 7 WAT, differences in parameters measured between the two mowing treatments were observed. Turf quality resulted higher for autonomous mowing (7.0) compared with rotary mowing (6.5) (Table 2). Autonomous mowing also had lower weed cover $(4 \%)$ compared with rotary mowing $(7 \%)$. Weeds found were field chamomile [Anthemis arvensis (95\%)], johnson grass [Sorghum halepense $(3 \%)]$, scarlet pimpernel [Anagallis arvensis (1\%)], and annual bluegrass [Poa annua (1\%)]. Disease incidence was unaffected by the two different mowing systems.

At 12 WAT, as expected, $\mathrm{N}$ fertilization increased turf quality values with respect to control that showed a low and unacceptable value of turf quality (4.8) (Table $\mathrm{l}$ ). $\mathrm{N}$ fertilization also improved mowing quality (average of 8.2), although without $\mathrm{N}$ fertilization mowing quality was acceptable (7.2). An interesting effect of $\mathrm{N}$ fertilization was the lower weed cover percentage (average 5.0\%) with respect to control (14\%). Disease incidence was affected by $\mathrm{N}$ fertilization, although differences were significant only between control (7.5) and $\mathrm{N}$-fertilized plots (average 8.4). At 12 WAT, N fertilization affected turf density with significant differences between con$\operatorname{trol}\left(2.2 \mathrm{shoot} / \mathrm{cm}^{2}\right)$ and $150 \mathrm{~kg} \cdot \mathrm{ha}^{-1}$ $\mathrm{N}\left(3.2\right.$ shoot $\left./ \mathrm{cm}^{2}\right)$ (Table 1). At the same time, leaf width was not impacted by $\mathrm{N}$ fertilization.

At 12 WAT, shoot density was significantly increased by autonomous mower (3.2 shoots $\left./ \mathrm{cm}^{2}\right)$ compared with rotary mower $\left(2.1\right.$ shoots $\left./ \mathrm{cm}^{2}\right)$ (Table 2). Leaf width was finer for the autonomous mower $(2.1 \mathrm{~mm}) \mathrm{com}$ pared with the rotary mower $(2.7 \mathrm{~mm})$. Turf quality resulted higher for autonomous mower (7.3) compared with rotary mower (6.4). Weed incidence resulted lower for autonomous mower compared with rotary mower $(6 \%$ and $9 \%$, respectively). Disease incidence and mowing quality were unaffected by the mowing system.

Operative characteristics of THE MOWING SYSTEMS. The operative characteristics of the autonomous mower and of the rotary mower are shown in Table 3. Autonomous mower operational time was set at $10 \mathrm{~h} \cdot \mathrm{d}^{-1}$, including mowing time and charging time. Overall mowing time was $7.8 \mathrm{~h}$, including $1.18 \mathrm{~h}$ of turning time (time spent to change direction). However, the autonomous mower does not stop mowing while turning. Actual daily mowing time, excluding turns, was $6.62 \mathrm{~h}$. Average working speed was $1.6 \mathrm{~km} \cdot \mathrm{h}^{-1}$ and working width was $24 \mathrm{~cm}$. The electric energy consumption was $2.21 \mathrm{kWh}$ per week, corresponding to $4.80 \mathrm{kWh}$ of primary energythe energy from primary sources which is transformed to electric energy - considering the efficiency of the Italian National Electric System equal 
Table 1. Nitrogen fertilization effect on tall fescue turf quality $(1=$ poor, $9=$ excellent $)$, mowing quality $(1=$ poorest mowing quality, 9 = cleanest cut), weed cover, and disease $(1=$ completely injury, $9=$ no injury $)$ after 7 and 12 weeks of treatment. At 12 weeks after treatment shoot density and leaf width are also indicated.

\begin{tabular}{|c|c|c|c|c|}
\hline \multicolumn{5}{|c|}{7 weeks after treatment } \\
\hline $\begin{array}{l}\text { Nitrogen fertilization } \\
\left(\mathrm{kg} \cdot \mathrm{ha}^{-1}\right)^{\mathrm{z}}\end{array}$ & $\begin{array}{l}\text { Turf quality } \\
\text { (1-9 scale) }\end{array}$ & $\begin{array}{c}\text { Mowing quality } \\
\text { (1-9 scale) }\end{array}$ & Weed cover $(\%)$ & $\begin{array}{c}\text { Disease } \\
(1-9 \text { scale })\end{array}$ \\
\hline 0 & 5.2 & 7.3 & 6 & 9 \\
\hline 50 & 6.2 & 8.0 & 6 & 9 \\
\hline 100 & 7.4 & 8.2 & 6 & 9 \\
\hline 150 & 7.8 & 8.2 & 5 & 9 \\
\hline
\end{tabular}

12 weeks after treatment

\begin{tabular}{|c|c|c|c|c|c|c|}
\hline $\begin{array}{l}\text { Nitrogen fertilization } \\
\left(\mathrm{kg} \cdot \mathrm{ha}^{-1}\right)\end{array}$ & $\begin{array}{l}\text { Turf quality } \\
\text { (1-9 scale) }\end{array}$ & $\begin{array}{l}\text { Mowing quality } \\
\text { (1-9 scale) }\end{array}$ & Weed cover $(\%)$ & $\begin{array}{c}\text { Disease } \\
(1-9 \text { scale })\end{array}$ & $\begin{array}{c}\text { Shoot density } \\
\left(\text { no. } / \mathrm{cm}^{2}\right)^{\mathrm{z}}\end{array}$ & $\begin{array}{l}\text { Leaf width } \\
(\mathrm{mm})^{\mathrm{z}} \\
\end{array}$ \\
\hline 0 & 4.8 & 7.2 & 14 & 7.5 & 2.2 & 2.3 \\
\hline 50 & 6.8 & 7.9 & 6 & 8.2 & 2.6 & 2.5 \\
\hline 150 & 8.3 & 8.3 & 4 & 8.7 & 3.2 & 2.4 \\
\hline LSD $0.05^{y}$ & 0.3 & 0.3 & 2 & 0.6 & 0.7 & NS \\
\hline
\end{tabular}

LSD = least significant difference; $\mathrm{NS}=$ nonsignificant.

${ }^{\mathrm{z}} \mathrm{l} \mathrm{kg} \cdot \mathrm{ha}^{-1}=0.8922 \mathrm{lb} /$ acre, 1 shoot $/ \mathrm{cm}^{2}=6.4516$ shoots $/ \mathrm{inch}^{2}, 1 \mathrm{~mm}=0.0394 \mathrm{inch}$.

'Fisher's LSD test at the 0.05 level.

Table 2. Mowing system treatment effects on tall fescue turf quality $(1=$ poor, $9=$ excellent $)$, mowing quality $(1=$ poorest mowing quality, $9=$ cleanest cut $)$, weed cover, and disease $(1=$ completely injury, $9=$ no injury $)$ after 7 and 12 weeks of treatment. At 12 weeks after treatment shoot density and leaf width are also indicated.

\begin{tabular}{lcccc}
\hline & T weeks after treatment & & \\
\hline Mowing system & $\begin{array}{c}\text { Turf quality } \\
\text { (1-9 scale) }\end{array}$ & $\begin{array}{c}\text { Mowing quality } \\
\text { (1-9 scale) }\end{array}$ & Weed cover (\%) & Disease \\
Rotary mower & 6.5 & 7.8 & 7 & 9 \\
Autonomous mower & 7.0 & 8.0 & 4 & 9 \\
LSD $0.05^{y}$ & 0.3 & NS & 1
\end{tabular}

12 weeks after treatment

\begin{tabular}{|c|c|c|c|c|c|c|}
\hline Mowing system & $\begin{array}{l}\text { Turf quality } \\
\text { (1-9 scale) }\end{array}$ & $\begin{array}{c}\text { Mowing quality } \\
\text { (1-9 scale) }\end{array}$ & Weed cover $(\%)$ & $\begin{array}{c}\text { Disease } \\
\text { (1-9 scale) }\end{array}$ & $\begin{array}{c}\text { Shoot density } \\
\left(\text { no. } / \mathrm{cm}^{2}\right)^{\mathrm{z}}\end{array}$ & $\begin{array}{c}\text { Leaf width } \\
(\mathrm{mm})^{\mathrm{z}} \\
\end{array}$ \\
\hline Rotary mower & 6.4 & 7.8 & 9 & 8.0 & 2.1 & 2.7 \\
\hline Autonomous mower & 7.3 & 8.0 & 6 & 8.4 & 3.2 & 2.1 \\
\hline LSD $0.05^{y}$ & 0.2 & NS & 2 & NS & 0.5 & 0.3 \\
\hline
\end{tabular}

LSD = least significant difference; $\mathrm{NS}=$ nonsignificant.

${ }^{\mathrm{z}} 1 \mathrm{shoot} / \mathrm{cm}^{2}=6.4516$ shoots $/$ inch $^{2}, 1 \mathrm{~mm}=0.0394$ inch.

${ }^{y}$ Fisher's LSD test at the 0.05 level.

to 0.46 to $1 \mathrm{kWh}$ of primary energy gives $0.46 \mathrm{kWh}$ of electric energy (European Union, 2014). The electric energy consumption was mainly due to mowing (power required about $30 \mathrm{~W}$ ). The power requirement for the boundary/guide wire was 86.4 Wh/d.

The gasoline walk behind mulching mower, which cut the grass once per week, covered the same area in $1.02 \mathrm{~h}$, with an average working speed of $3 \mathrm{~km} \cdot \mathrm{h}^{-1}$ and a working width of $53 \mathrm{~cm}$. Turning time did not considerably affect the total operative time (only 0.06 $\mathrm{h} /$ week). The maximum engine power was $5 \mathrm{~kW}$. Gasoline consumption was about $1.36 \mathrm{~L} /$ week, and the total primary energy was $12.60 \mathrm{kWh}$, assuming the heating value of the gasoline equal to $9.2 \mathrm{kWh} / \mathrm{L}$ (Table 3 ).

Comparing the two mowing systems from an operative point of view, the autonomous mower cuts everyday and needs $10 \mathrm{~h} \cdot \mathrm{d}^{-1}$ to autonomously manage the experimental plots (mowing plus charging). The walk behind gasoline rotary mower cuts once per week and needs $1.02 \mathrm{~h}$ to cut the experimental plot but requires human labor. Despite the higher working time required, the autonomous mower showed a lower energetic consumption, 4.80 vs. $12.60 \mathrm{kWh} /$ week.
Concerning costs, the estimated value is lower for the autonomous mower with respect to the ordinary rotary mower if considering the Italian ordinary labor cost (19.36 vs. 32.22 euros/week) (Table 3 ).

\section{Discussion}

In this trial, average turf height was lower where autonomous mower was employed because turfgrass was mowed everyday while rotary mower operated only once per week. The lower average turf height may have improved shoot density, turf quality, and reduced leaf width. 
Table 3. Operative characteristics, energy consumption, and estimated costs of the autonomous mower and of the rotary mower working on a surface of $1296 \mathrm{~m}^{2}\left(1550.0\right.$ yard $\left.^{2}\right)$ at $3.5 \mathrm{~cm}(1.38$ inch $)$ mowing height.

\begin{tabular}{llr}
\hline Parameter & \multicolumn{1}{c}{ Unit $^{\mathbf{z}}$} & Value \\
\hline Autonomous mower & & \\
Working speed & $\mathrm{km} \cdot \mathrm{h}^{-1}$ & 1.60 \\
Working width & $\mathrm{cm}$ & 24.00 \\
Set daily working time (mowing and recharging) & $\mathrm{h} \cdot \mathrm{d}^{-1}$ & 10.00 \\
Daily mowing time (no recharging) & $\mathrm{h} \cdot \mathrm{d}^{-1}$ & 7.80 \\
Electric energy consumption per week & $\mathrm{kWh} /$ week & 2.21 \\
Primary energy consumption per week & $\mathrm{kWh} /$ week & 4.80 \\
Cost per week & euros/week & 19.36 \\
Rotary mower & & \\
Engine power & $\mathrm{kW}$ & 5.00 \\
Working speed & $\mathrm{km} \cdot \mathrm{h}^{-1}$ & 3.00 \\
Working width & $\mathrm{cm}$ & 53.00 \\
Total operative time & $\mathrm{h} /$ week & 1.02 \\
Gasoline consumption & $\mathrm{L} /$ week & 1.36 \\
Primary energy consumption & $\mathrm{kWh} /$ week & 12.60 \\
Cost per week (included labor 25 euros $/ \mathrm{h}$ ) & $\mathrm{euros} /$ week & 32.22 \\
\hline
\end{tabular}

${ }^{\mathrm{z}} 1 \mathrm{~km} \cdot \mathrm{h}^{-1}=0.6214 \mathrm{mph}, 1 \mathrm{~cm}=0.3937 \mathrm{inch}, \mathrm{l} \mathrm{L}=0.2642 \mathrm{gal}$.

Previous research carried out on tall fescue tolerance to mowing (Grossi et al., 2004), ranging from 1.0 to $2.5 \mathrm{~cm}$, showed that $1.0-\mathrm{cm}$ mowing height reduced leaf width (mean leaf width $2.0 \mathrm{~mm}$ ), increased highest density (4.4 shoots $/ \mathrm{cm}^{2}$ ), and enhanced turf quality compared with higher heights.

The lower power requirement of the autonomous mower could be mainly due to the lower power needed for mowing (the maximum power requirement of the machine is only $40 \mathrm{~W}$ ) as the turfgrass is daily mowed and the machine only cuts small clippings. The overall efficiency of the autonomous mower is higher than the efficiency of the gasoline mower. The electric brushless motors have an efficiency of about $90 \%$ and the Italian National Electric System has an efficiency of 0.46 with an overall efficiency of about 0.40 . The overall efficiency of a small gasoline engine ranges from 0.20 to 0.25 and uses primary energy. The electric consumption of the autonomous mower is $2.21 \mathrm{kWh} /$ week, which results in less than 0.5 euro/week (the Italian average cost of the electric energy is about 0.20 euro $/ \mathrm{kWh}$ ). However the price of the autonomous mower is higher than the price of an ordinary gasoline mower (it usually ranges from 2000 to 3000 euros depending on turf dimension and autonomous mower model, vs. 700-800 euros for a standard walk behind rotary mower). The autonomous mower does not require labor time and the total number of operating hours expected for an autonomous mower is much higher than the number of operating hours of a rotary mower. Moreover the two different mowing systems are not equal from a turf quality point of view. Cutting frequently leads to a better turf quality, so this effect probably could not be due only to the autonomous robot itself but also to the combined effect of autonomous robot and high mowing frequency.

As expected, $\mathrm{N}$ fertilization increased turf quality, shoot density, and mowing quality with respect to nonfertilized control plots. After 12 weeks, daily autonomous mowing increased turf density compared with rotary mower across all $\mathrm{N}$ rates. Leaf width was finer for autonomous mower compared with rotary mower. Turf quality was higher for autonomous mower compared with rotary mower. Weed incidence was lower where autonomous mower was employed. Based on turf quality aspects and energy consumption, the use of the autonomous mower could be a promising alternative to traditional human operated combustion mowers. The use of the automatic mower could be differently appreciated depending on the tradition of the country. In Italy, for example, mowing the grass is generally considered a weekend nuisance, whereas in other countries, like the United States, the lawn care is often a pleasant exercise.

\section{Conclusion}

However, automatic mowers can always be a good solution for people who do not have enough time or have physical disadvantages (disabled people or very old people). Further research is needed to test the effects of autonomous mowing on weed control and on warm season turfgrasses, which has peculiar mowing requirements.

\section{Literature cited}

Beard, J.B. 1973. Turfgrass: Science and culture. Prentice Hall, Englewood Cliffs, NJ.

Chang, C.L., C. Yang, and G.B. Song. 2015. Integration of laser scanner and odometry for autonomous robotics lawnmower. Amer. Soc. Agr. Biol. Eng. Annu. Intl. Mtg. 6:4794-4801.

Etesia. 2016. They mow every day, without you. 24 Aug. 2016. <http://www. etesia.com/en/products/robot-etml 05 . html>.

European Union. 2014. Italian national efficiency action plan. 24 Aug. 2016. $<$ https://ec.europa.eu/energy/sites/ ener/files/documents/2014_neeap_en_ italy.pdf>

Grossi, N., M. Volterrani, S. Magni, and S. Miele. 2004. Tall fescue turf quality and soccer playing characteristics as affected by mowing height. Acta Hort. 661:319-322.

Gupta, V. 2014. Energy management in parallel hybrid electric vehicles combining neural networks and equivalent consumption minimization strategy. Open Intl. J. Technol. Innovations Res. 10:1-14

Hicks, R.W., II., and E.L. Hall. 2000. Survey of robot lawn mowers, p. 262-269. Proc. SPIE 4197. Intelligent Robots and Computer Vision XIX: Algorithms, Techniques, and Active Vision. Boston, MA.

Honda. 2016. Miimo at a glance. 24 Aug. 2016. <http://www.honda.co.uk/lawnand garden/products/miimo-2015/ overview.html>.

Husqvarna. 2015. Husqvarna automower $105 / 310 / 315 / 320 / 330 \mathrm{X} / 420 /$ 430X/450X operator's manual. 24 Aug. 2016. <http://www.husqvarna.com/ uk/support/manuals-downloads/>.

Lu, X., Y. Liu, H. Du, and S. Xu. 2014. The uncut lawn cognition algorithm based on image analysis. Proc. 1lth World Congr. Intelligent Control Automation. 5138-5142.

MacRae, M. 2013. Robots cut grass with class. Mech. Eng. 135(9):12-19.

Morris, K.N. and R.C. Shearman. 2014. NTEP turfgrass evaluation guidelines. 11 June 2014. <http:/ / www.ntep.org/pdf/ ratings $>$. 


\section{Preliminary and Regional Reports}

Ragonese, A. and J. Marx. 2015. The applications of sensor technology in the design of the autonomous robotic lawn mower, Paper No. 5094. 15th Annu. Freshman Eng. Conf., 11 Apr. 2015, Pittsburgh, PA.

Robomow. 2016. Choose your best team player. 24 Aug. 2016. <http://robomow. com/en-GB/product-category/mowers/>.

Sheffer, K.M., T.L. Watschke, and J.M. Duich. 1978. Effect of mowing height on leaf angle, leaf number, and tiller density of 62 kentucky bluegrasses. Agron. J. 70:686-689
Shepard, D.P., J.I.M. Dipaola, and W.M. Lewis. 1989. Effects of clipping regime on turf quality and mowing requirement. Agron Abstr. 165.

Starr, J.L. and H.C. DeRoo. 1981. The fate of nitrogen fertilizer applied to turfgrass. Crop Sci. 21:531-536.

Tang, Q. and W. Schiehlen. 2014. From lawnmower dynamics to modelling, simulation and experiments of a differentially driven robot, p. 365-374. In: M Ceccarelli and V.A. Glazunov (eds.). Advances on theory and practice of robots and manipulators. Springer Intl. Publ., Basel, Switzerland.

Turgeon, A.J. 1980. Turfgrass management. Reston Publ., Reston, VA.

Volterrani, M. and S. Magni. 2004. Species and growing media for sports turfs in Mediterranean area. Acta Hort. 66:359364.

Zucchetti. 2016. Ambrogio robot. 24 Aug. 2016. <http://www.ambrogiorobot.com/ en/ambrogiorobot>. 